\title{
Nutrient uptake of soybean genotypes under aluminum toxicity
}

\author{
Heru Kuswantoro \\ Indonesian Legume and Tuber Crops Research Institute, Indonesian Agency for Agricultural \\ Research and Development, Malang, Indonesia
}

\begin{abstract}
The objective of this research was to study the nutrient uptake of soybean exposed to aluminium (Al) toxicity. The factorial design consisted of two treatments arranged in a randomized block design with three replications. Liming was the first factor which consisted of four levels, i.e. i) without liming; ii) liming with $0.5 \times \mathrm{Al}($ exchangeable/ec); iii) liming with $1 \times \mathrm{Al}(\mathrm{ec})$; and iv) liming with $1.5 \times \mathrm{Al}(\mathrm{ec})$. Five genotypes were used as second factor, i.e. three tolerant genotypes (W389814-3, Wilis, and Kawi), and two sensitve genotypes (MLG 3209 and MLG 3083). It was found that two tolerant genotypes, W3898-14-3 and Kawi, had a higher potassium $(\mathrm{K})$ and sodium $(\mathrm{Na})$ uptake than susceptible genotypes. Liming affected significantly the ratio of $\mathrm{AV} /[$ calcium (Ca) + magnesium (Mg)] in roots and leaves, the content of $\mathrm{Ca}$ and $\mathrm{Mg}$ in the roots and the content of $\mathrm{Mg}$ in the leaves. The $\mathrm{K}$ content in the roots and the content of $\mathrm{Ca}, \mathrm{K}$, and $\mathrm{Na}$ in the leaves were unresponsive to the alteration of $\mathrm{pH}$ and $\mathrm{Al}$ saturation.
\end{abstract}

\section{Introduction}

Among the earth's crust minerals, aluminum (Al) is the third most abundant after oxygen and silicon (Bhalerao and Prabu, 2013). It can have

Correspondence: Heru Kuswantoro, Indonesian Legume and Tuber Crops Research Institute, Indonesian Agency for Agricultural Research and Development, Jl. Raya Kendalpayak Km. 8, PO Box 66 Malang 65101, Indonesia.

E-mail: heru@litbang.deptan.go.id

Key words: aluminium toxicity, calcium, potassium, magnesium, sodium, soybean.

Acknowledgements: the author wish to thank the Ministry of National Education of the Republic of Indonesia for supporting the research through University Research for Graduate Education (URGE) project.

Received for publication: 14 March 2014.

Revision received: 30 July 2014.

Accepted for publication: 30 July 2014.

(C) Copyright H. Kuswantoro et al., 2014

Licensee PAGEPress, Italy

Italian Journal of Agronomy 2014; 9:600

doi:10.4081/ija.2014.600

This article is distributed under the terms of the Creative Commons Attribution Noncommercial License (by-nc 3.0) which permits any noncommercial use, distribution, and reproduction in any medium, provided the original author(s) and source are credited. a toxic effect on plants under specific soil conditions, especially when the soil is acid. The root is the plant organ most affected by Al toxicity, before the upper part organs (Meriño-Gergichevich et al., 2010). However, some plants can tolerate Al toxicity, whereas other cannot tolerate it at all. This suggests that there is a specific mechanism associated with Al toxicity tolerance. Al-tolerant plants can be classified in three groups according to the plant tissues that accumulate $\mathrm{Al}$ (Foy, 1984). The first group includes plants in which the Al concentration in the leaves is not always different from that of sensitive plants and remains at lower levels. The second group includes plants with no $\mathrm{Al}$ in the leaves and/or Al trapped in the roots. The third group includes plants in which Al tolerance is directly related to $\mathrm{Al}$ accumulation in the upper part of the plant. These plants have therefore a high internal tolerance towards Al. In principle, the mechanisms of Al tolerance facilitate Al exclusion from the root and/or confer the plant the ability to tolerate it in its organs (Vardar and Unal, 2007). Watanabe and Osaki (2002) proposed other Al toxicity tolerance mechanisms by classifying plant into two groups. The first group includes the $\mathrm{Al}$ excluders, i.e. plants that exclude Al from their organs. The second group includes the Al accumulators, i.e. the plants that inactivate $\mathrm{Al}$ in their organs. Al accumulator plants present specific mechanisms involved in tolerance, such as the immobilization of Al in the cell wall, cytoplasmic Al complexation by organic acids, vacuolar isolation of Al tolerant enzymes, and isolation of Al in the vacuoles (Sopandie et al., 2000). Inorganic nutrients are also involved in this mechanism due to the interaction of Al with other nutrients to form inactive molecules. When Al concentration increases, the concentrations of magnesium $(\mathrm{Mg})$, calcium $(\mathrm{Ca})$, potassium $(\mathrm{K})$, and sodium $(\mathrm{Na})$ decrease in the foliage and the roots (Bojarczuk et al., 2006). However liming can increase $\mathrm{Ca}, \mathrm{Mg}, \mathrm{K}$, and $\mathrm{Na}$ in both the soil and the plant; because it increases the soil $\mathrm{pH}$, thus increasing the availability of $\mathrm{Ca}, \mathrm{Mg}, \mathrm{K}$, and $\mathrm{Na}$ in the soil itself. Some studies reported that the use of $\mathrm{Ca}$ and $\mathrm{Mg}$ led to a decrease of $\mathrm{Al}$ in the soil and the plants (Wang and Kao, 2004; Loide, 2004), because the presence of $\mathrm{Ca}$ and $\mathrm{Mg}$ can precipitate $\mathrm{Al}$. On the contrary, the binding of $\mathrm{Al}^{3+}$ to negative charges and the precipitation of $\mathrm{Al}$ in the apoplast may decrease the loading of $\mathrm{Mg}^{2+}$ ions (Bose et al., 2011). The effect of $\mathrm{Mg}$ is ion-specific and is not only associated to an electrostatic protection mechanism (da Silva et al., 2008). Being a cation, K can also potentially decrease Al toxicity. Na was also reported among nutrients that can decrease Al toxicity (Maas et al., 2000). The tissue concentration of these nutrients may vary among soybean genotypes. The tolerant group shows higher concentrations of $\mathrm{Mg}$ and $\mathrm{Ca}$ than the sensitive group (Yan et al., 2009). Changes in the content of these nutrients in roots (Bojarczuk et al., 2006) and leaves (Poolpipatana and Hue, 1994) indicate that these traits can be useful tolerance or sensitive indicators (Bojarczuk et al., 2006; Poolpipatana and Hue, 1994).

\section{Materials and methods}

\section{Soil preparation}

Before planting, the soil was limed with dolomite. Soil and dolomite (39\% $\mathrm{CaO}$ and $21 \% \mathrm{Mg}$ ) were mixed to obtain a homogenous soil medium. The mixture was then incubated for $30 \mathrm{~d}$ to enable the reaction 
Table 1. Nutrient content of the soil with liming at $0.0 \times \mathrm{Al}(\mathrm{ec}), 0.5 \times \mathrm{Al}(\mathrm{ec}), 1 \times \mathrm{Al}(\mathrm{ec})$, and $1.5 \times \mathrm{Al}(\mathrm{ec})$.

\begin{tabular}{|c|c|c|c|c|}
\hline \multirow[t]{2}{*}{ Soil properties } & \multicolumn{4}{|c|}{ Liming } \\
\hline & $0 \times \mathrm{Al}(\mathrm{ec})$ & $0.5 \times \mathrm{Al}(\mathrm{ec})$ & $1 \times A l(e c)$ & $1.5 \times \mathrm{Al}(\mathrm{ec})$ \\
\hline $\mathrm{pH} \mathrm{H}_{2} \mathrm{O}$ & 4.95 & 5.65 & 6.2 & 6.6 \\
\hline $\mathrm{pH} \mathrm{KCl}$ & 4.1 & 4.6 & 5.25 & 5.8 \\
\hline $\mathrm{K}\left(\mathrm{Cmol} \mathrm{kg}^{-1}\right)$ & 0.16 & 0.22 & 0.28 & 0.29 \\
\hline $\mathrm{Na}\left(\mathrm{Cmol} \mathrm{kg}^{-1}\right)$ & 0.46 & 0.58 & 0.62 & 0.79 \\
\hline $\mathrm{Ca}\left(\mathrm{Cmol} . \mathrm{kg}^{-1}\right)$ & 1.81 & 2.97 & 9.88 & 16.86 \\
\hline $\operatorname{Mg}\left(\mathrm{Cmol} \mathrm{kg}^{-1}\right)$ & 0.37 & 1.14 & 3.23 & 7.84 \\
\hline CEC $\left(\mathrm{Cmol}^{2} \mathrm{~kg}^{-1}\right)$ & 4.4 & 8.8 & 17.6 & 22 \\
\hline $\mathrm{CEC}_{\text {effective }}\left(\mathrm{Cmol} \mathrm{kg}^{-1}\right)$ & 4.57 & 6.36 & 15.01 & 26.11 \\
\hline $\mathrm{Al}_{\text {saturation }}(\%)$ & 27.13 & 15.88 & 4.59 & 0.19 \\
\hline
\end{tabular}

$\mathrm{Al}(\mathrm{ec})$, aluminium exchangable; K, potassium, Na, sodium, Ca, calcium, Mg, magnesium.

between soil and lime to take place. During the incubation period, every four days the soil was watered to maintain soil moisture under field capacity conditions. Planting was performed in a polybag with a capacity of $10 \mathrm{~kg}$ of soil with two plants per polybag.

\section{Greenhouse experiment}

The greenhouse experiment was conducted with Ultisol soils in the province of Lampung-Indonesia. The design was factorial, included two factors, and was arranged in a randomised complete block with three replications. The first factor was liming which consisted of four levels, i.e. i) without liming; ii) liming with $0.5 \times \mathrm{Al}($ exchangeable/ec); iii) liming with $1 \times \mathrm{Al}(\mathrm{ec})$; and iv) liming with $1.5 \times \mathrm{Al}(\mathrm{ec})$. The second factor was the genotype which consisted of five genotypes: three tolerant genotypes (W 3898-14-3, Wilis, and Kawi) and two sensitive genotypes (MLG MLG 3209 and 3083).

\section{Plant nutrient analysis}

Plant nutrient contents were measured during the flowering stage. Measurements were carried out on the physiological characters, such as content of nutrients like $\mathrm{Al}, \mathrm{K}, \mathrm{Na}, \mathrm{Ca}$, and $\mathrm{Mg}$ in roots and leaves. Before plant nutrients were analysed, shoots and roots were separated, and then roots were washed under running water to eliminate the soil. The clean shoots and roots were dried under the sunshine. The five nutrients were analysed by grinding the roots and the leaves with a grinding mill. Then they were subsequently put in an acid solution for further destruction. The materials were then diluted and observed under an atomic absorption/flame emission spectrophotometer (AAShimidzu 630-12) to measure the content of $\mathrm{Al}, \mathrm{Ca}$, and $\mathrm{Mg}$, and under a flame photometer (CORNING Flamephotometer 410) to measure the content of $\mathrm{K}$ and $\mathrm{Na}$.

\section{Results and discussion}

Liming increased the $\mathrm{pH}$ from 4.95 up to $5.65,6.20$ and 6.60 at $0.5 \times \mathrm{Al}(\mathrm{ec}), 1 \times \mathrm{Al}(\mathrm{ec})$, and $1.5 \times \mathrm{Al}(\mathrm{ec})$ respectively. Consequently, the macronutrients increased and the micronutrients decreased (Table 1). The highest increase was shown by $\mathrm{Ca}$ after applying liming at 1.5 $\mathrm{Al}(\mathrm{ec}) . \mathrm{Mg}$ and $\mathrm{Na}$ also increased significantly after $\mathrm{Ca}$. In general, the nutrients increased significantly at $1 \times \mathrm{Al}(\mathrm{ec})$ and tended to flatten out at $1.5 \times \mathrm{Al}(\mathrm{ec})$. Similar results were also reported by other authors (Pengshouvana et al., 2009) showing that liming increased the concentration of $\mathrm{Ca}$ and $\mathrm{Mg}$, but decreased $\mathrm{Al}$ in the soil. This effect is due to
Table 2. Effect of liming on calcium (Ca) and magnesium $(\mathrm{Mg})$ uptake and aluminium/ $(\mathrm{Ca}+\mathrm{Mg})$ ratio in root of soybean genotypes.

\begin{tabular}{lccc} 
Liming & $\mathrm{Ca}(\mathrm{ppm})$ & $\mathrm{Mg}(\mathrm{ppm})$ & $\mathrm{AN} /(\mathrm{Ca}+\mathrm{Mg})$ \\
$0 \times \mathrm{Al}(\mathrm{ec})$ & $306.98^{\mathrm{c}}$ & $1551.25^{\mathrm{c}}$ & $80.30^{\mathrm{a}}$ \\
$0.5 \times \mathrm{Al}(\mathrm{ec})$ & $349.62^{\mathrm{b}}$ & $2383.83^{\mathrm{b}}$ & $53.27^{\mathrm{b}}$ \\
\hline $1 \times \mathrm{Al}(\mathrm{ec})$ & $406.30^{\mathrm{a}}$ & $2566.44^{\mathrm{ab}}$ & $48.22^{\mathrm{b}}$ \\
$1.5 \times \mathrm{Al}(\mathrm{ec})$ & $370.70^{\mathrm{b}}$ & $2692.18^{\mathrm{a}}$ & $42.43^{\mathrm{b}}$ \\
\hline
\end{tabular}

$\mathrm{Ca}$, calcium; $\mathrm{Mg}$, magnesium; $\mathrm{Al}(\mathrm{ec})$, aluminium exchangable. a,b,c Values in the same column followed by the same letter were not significantly different with Duncan's multiple range test of $5 \%$.

the ability of lime to increase the soil $\mathrm{pH}$, thus increasing macronutrient solubility, yet decreasing micronutrient solubility, including Al solubility.

The variance analysis of the nutrient contents in soybean roots showed a significant difference in the contents of $\mathrm{Ca}, \mathrm{Mg}, \mathrm{K}$ and $\mathrm{Al} /(\mathrm{Ca}+\mathrm{Mg})$ ratio, whereas $\mathrm{Al}$ and $\mathrm{Na}$ were not significantly different (data not shown). Unlike other nutrients, the content of $\mathrm{Mg}$ in the leaves of soybean was significantly different. The genotype factor also showed a significant difference in relation to the content of $\mathrm{K}, \mathrm{Ca}$, and $\mathrm{Na}$, thus explaining the difference in the uptake of the three nutrients in each genotype. A similar result was also reported by Lee (1989).

The increase in lime led to an increased uptake of $\mathrm{Ca}$ and $\mathrm{Mg}$, but the $\mathrm{Al} /(\mathrm{Ca}+\mathrm{Mg})$ ratio decreased (Table 2). Ca uptake increased from $0.5 \times \mathrm{Al}(\mathrm{ec})$ to $1 \times \mathrm{Al}(\mathrm{ec})$, but it decreased at $1.5 \times \mathrm{Al}(\mathrm{ec})$. On the contrary, $\mathrm{Mg}$ uptake increased up to $1.5 \times \mathrm{Al}(\mathrm{ec})$. A similar result was also reported by another study (Keltjens, 1990) which showed that an increasing concentration of $(\mathrm{Ca}+\mathrm{Mg})$ in the medium also increased concentrations of $\mathrm{Ca}$ and $\mathrm{Mg}$ in roots and shoots. The highest $\mathrm{Al} /(\mathrm{Ca}+\mathrm{Mg})$ ratio was reached with no liming and decreased under liming conditions. There was no statistically significant difference in Al uptake in roots and leaves under liming conditions, probably due to the interaction of $\mathrm{Al}$ with $\mathrm{Ca}$ and $\mathrm{Mg}$. This can be explained by the $\mathrm{Al} / \mathrm{Ca}+\mathrm{Mg})$ ratio in roots and leaves, which was significantly different under liming condition (Tables 2 and 3). This occurred because Al can interact with other nutrients, which can therefore neutralise its detrimental effect.

Root Ca uptake increased, as liming increased with the highest uptake occurring at $1 \times \mathrm{Al}(\mathrm{ec})$ (Table 2). This showed that root $\mathrm{Ca}$ uptake was more influenced by the environmental factors rather than the genotype factors. Ca plays a fundamental role in $\mathrm{Al}-\mathrm{Ca}$ interactions in the improvement of Al toxicity (Meriño-Gergichevich et al., 2010). The increase in $\mathrm{Ca}$ uptake was caused by the neutralization due to liming and not by the addition of $\mathrm{Ca}$ in Ca-deficient plants (Sunarto, 
1985). In this experiment, the increase in soil Ca availability was affected by both neutralisation and $\mathrm{Ca}$ addition. This can be explained by the sharp increase in the Ca content, although the soil $\mathrm{pH}$ did not increase significantly. The low root $\mathrm{Ca}$ uptake at $1.5 \times \mathrm{Al}(\mathrm{ec})$ occurred because this liming level had already influenced significantly the availability of soil $\mathrm{Ca}$. Furthermore, at certain concentrations, Al may enhance the absorption of $\mathrm{Ca}$ in the roots. Nursyamsi et al. (2000) reported that a concentration of $5 \mathrm{ppm}$ of $\mathrm{Al}$ can stimulate $\mathrm{Ca}$ uptake. Increasing $\mathrm{Ca}$ uptake by the roots was reported by Ferufino et al. (2000), indicating that Ca uptake was higher in lateral roots than in the taproot. Ca uptake in cells led to favorable conditions for cell enlargement and root cell extension (Blamey, 2003; Okada et al., 2003). $\mathrm{Ca}$ application decreased the Al content in the root tips (Watanabe and Okada, 2005).

$\mathrm{Mg}$ uptake in roots and leaves increased with the increase in lime. However, when liming exceeded $0.5 \times \mathrm{Al}(\mathrm{ec}), \mathrm{Mg}$ uptake in the leaves did not increase (Table 3), but it kept increasing in the roots (Table 2). Increasing $\mathrm{Mg}$ uptake in the leaves with increasing $\mathrm{Al}(\mathrm{ec})$ was also reported by Pan et al. (1989). Increasing Mg uptake in the roots and leaves was triggered by increasing $\mathrm{Mg}$ in the soil due to liming. Increasing $\mathrm{Mg}$ in the soil was affected by increasing soil $\mathrm{pH}$ that lead to better soil conditions for $\mathrm{Mg}$ availability, and increasing $\mathrm{Mg}$ as liming materials (dolomite). In addition, the plant Mg uptake was strongly influenced by $\operatorname{Mg}(\mathrm{ec})$ and soil $\mathrm{pH}$. A similar result was reported by Basri et al. (1991) who stated that Mg absorption decreased by liming with a low Mg content material.

An interaction was identified between the genotype and the environment in relation to $\mathrm{K}$ uptake in the roots (Table 4). Genotypes W3898$14-3$ and Wilis showed the highest root $\mathrm{K}$ uptake at $1.5 \times \mathrm{Al}(\mathrm{ec})$. The Kawi genotype showed the highest $K$ uptake with no liming. Sensitive genotype MLG 3209 also showed the highest $\mathrm{K}$ uptake at $1.5 \times \mathrm{Al}(\mathrm{ec})$, while MLG 3083 showed the highest $\mathrm{K}$ uptake at $1 \times \mathrm{Al}(\mathrm{ec})$. The interaction between the genotypes and liming indicated that both the genotype and the environment equally influenced $\mathrm{K}$ uptake. However, Al can also inhibit $\mathrm{K}^{+}$uptake by blocking $\mathrm{K}$ inward (Liu and Luan, 2001), thus leading to a decreasing $\mathrm{K}$ uptake.

The effect of liming on the uptake of $\mathrm{Mg}$ and $\mathrm{Al} /(\mathrm{Ca}+\mathrm{Mg})$ ratio in the leaves showed that $\mathrm{Mg}$ uptake in leaves increased when liming increased, whereas the $\mathrm{Al} /(\mathrm{Ca}+\mathrm{Mg})$ ratio decreased (Table 3$)$. A significant difference was identified between control and liming treatments, but not among liming treatments. This indicates that liming at $0.5 \times \mathrm{Al}(\mathrm{ec})$ could increase $\mathrm{Mg}$ uptake, whereas there was no increasing $\mathrm{Mg}$ uptake with liming doses higher than at $0.5 \times \mathrm{Al}(\mathrm{ec})$. Andric et al. (2012) also reported that liming treatment significantly decrease $\mathrm{Mg}$ concentrations in leaves. Like in Mg uptake, a significant difference was seen between control and liming treatments, but not among liming treatments. A decreasing $\mathrm{Al} /(\mathrm{Ca}+\mathrm{Mg})$ ratio is in line with the increasing of $\mathrm{Mg}$ uptake in the leaves, since $\mathrm{Mg}$ is the component of the ratio.
Beside, Ca uptake in leaves was low lead the contribution to the $\mathrm{Al} /(\mathrm{Ca}+\mathrm{Mg})$ ratio was not significant.

The interaction between the genotype and the environment indicated by $\mathrm{Ca}$ uptake in the leaves is reported in Table 5. W3898-14-3 achieved the highest uptake at $0.5 \times \mathrm{Al}(\mathrm{ec})$, whereas Willis and Kawi achieved it at $1.5 \times \mathrm{Al}(\mathrm{ec})$ and $1 \times \mathrm{Al}(\mathrm{ec})$ respectively. MLG 3209 reached the highest $\mathrm{Ca}$ uptake at $1 \times \mathrm{Al}(\mathrm{ec})$ and the lowest at $1.5 \times \mathrm{Al}(\mathrm{ec})$. The highest Ca uptake in the leaves in MLG 3083 occurred at $0.5 \times \mathrm{Al}(\mathrm{ec})$, while the lowest at $1 \times \mathrm{Al}(\mathrm{ec})$ although no statistically significant difference was identified between $0 \times \mathrm{Al}(\mathrm{ec})$ and $1.5 \times \mathrm{Al}(\mathrm{ec})$. Ca uptake in the leaves showed an interaction between the genotype and liming, thus proving that both genotype and environmental factors had an influence on Ca uptake in the leaves. The interaction between the genotypes and the environment lead to a different response of the genotypes to the environmental changes (Table 5). Nursyamsi et al. (2000) also showed an increase in $\mathrm{Ca}$ uptake in the leaves, when $\mathrm{Al}$ concentration decrease.

Genotypes W3898-14-3, MLG 3209 and Kawi showed a higher K and $\mathrm{Na}$ uptake in the leaves than Willis and MLG 3083 (Table 6). As to Na uptake, MLG 3209 was not significantly different from MLG 3083 . The relationship of $\mathrm{K}$ and $\mathrm{Na}$ uptake with plant tolerance to acidic soils has not been widely studied. In general $\mathrm{K}$ and $\mathrm{Na}$ uptake also determine $\mathrm{Al}$ saturation in the soil. In this experiment root K uptake was not significantly different in the liming treatments, whereas leaf $\mathrm{K}$ uptake was significantly different among the genotypes (Table 6). Acid soil tolerant genotypes and Kawi W3898-14-3 showed a high uptake of $\mathrm{K}$ in the leaves and were significantly different from susceptible genotype MLG 3083. Basri et al. (1991) reported a decreased K uptake with increasing liming. The decreasing $\mathrm{K}$ uptake is due to the $\mathrm{Ca}^{2+}$ competitive effect on $\mathrm{K}$, because increased liming lead to the dominance of $\mathrm{Ca}^{2+}$ in the absorption site.

Uptake of $\mathrm{Na}$ in the leaves was also significantly different among the genotypes (Table 6). Similar to the K uptake in the leaves, the leaf $\mathrm{Na}$ uptake of acid-tolerant genotypes W3898-14-3 and Kawi showed high

Table 3. Effect of liming on magnesium (Mg) uptake and alu$\mathrm{minium} /($ calcium $+\mathrm{Mg})$ ratio in soybean leaves.

\begin{tabular}{lcc} 
liming & Mg (ppm) & $\mathrm{A} /(\mathrm{Ca}+\mathrm{Mg})$ \\
$0 \times \operatorname{Al}(\mathrm{ec})$ & $3354.74^{\mathrm{b}}$ & $11.29^{\mathrm{a}}$ \\
$0.5 \times \mathrm{Al}(\mathrm{ec})$ & $4424.26^{\mathrm{a}}$ & $7.53^{\mathrm{b}}$ \\
\hline $1 \times \mathrm{Al}(\mathrm{ec})$ & $4331.95^{\mathrm{a}}$ & $8.62^{\mathrm{b}}$ \\
$1.5 \times \mathrm{Al}(\mathrm{ec})$ & $4296.78^{\mathrm{a}}$ & $8.27^{\mathrm{b}}$ \\
\hline
\end{tabular}

$\mathrm{Mg}$, magnesium; Ca, calcium; $\mathrm{Al}(\mathrm{ec})$, aluminium exchangeable. a,bValues in the same column followed by the same letter were not significantly different at Duncan's multiple range test $5 \%$.

Table 4. Effect of liming on potassium uptake in roots of soybean genotypes.

\begin{tabular}{|c|c|c|c|c|}
\hline \multirow[t]{2}{*}{ Genotypes } & \multicolumn{4}{|c|}{$\mathrm{K}(\mathrm{ppm})$} \\
\hline & $0 \times \operatorname{Al}(\mathrm{ec})$ & $0.5 \times \mathrm{Al}(\mathrm{ec})$ & $1 \times \operatorname{Al}(e c)$ & $1.5 \times \mathrm{Al}(\mathrm{ec})$ \\
\hline W 3898-14-3 & $10,149.92^{\mathrm{b}-\mathrm{e}}$ & $11,249.15^{\mathrm{ab}}$ & $11,552 \cdot 11^{\mathrm{ab}}$ & $13,147.80^{\mathrm{a}}$ \\
\hline Wilis & $10,549.64^{b-d}$ & $12,148.51^{\mathrm{ab}}$ & $11449.01^{\mathrm{ab}}$ & $13,047.87^{\mathrm{a}}$ \\
\hline Kawi & $11,648.86^{\mathrm{ab}}$ & $5853.67^{\mathrm{h}}$ & $7451.83^{\mathrm{f}-\mathrm{h}}$ & $7152.04^{\text {gh }}$ \\
\hline MLG 3209 & $8750.91^{\mathrm{c}-\mathrm{g}}$ & $8351.62^{\mathrm{d}-\mathrm{g}}$ & $6652.40^{\text {gh }}$ & $9750.21^{\mathrm{b}-\mathrm{f}}$ \\
\hline MLG 3083 & $8251.27^{\mathrm{d}-\mathrm{g}}$ & $8752.33^{\mathrm{c}-\mathrm{g}}$ & $10849.43^{\mathrm{a}-\mathrm{c}}$ & $7951.48^{\mathrm{e}-\mathrm{h}}$ \\
\hline
\end{tabular}

K, potassium; $\mathrm{Al}(\mathrm{ec})$, aluminium exchangeable. a,b,c,d,e,f,g,hValues followed by the same letter were not significantly different at Duncan's multiple range test $5 \%$. 
Table 5. Effect of liming on calcium uptake in the leaves of soybean genotypes.

\begin{tabular}{|c|c|c|c|c|}
\hline \multirow[t]{2}{*}{ Genotypes } & \multicolumn{4}{|c|}{$\mathrm{Ca}(\mathrm{ppm})$} \\
\hline & OxAl(ec) & $0.5 \times \mathrm{Al}(\mathrm{ec})$ & $1 \times A I(e c)$ & $1.5 \times \mathrm{Al}(\mathrm{ec})$ \\
\hline W 3898-14-3 & $1059.61^{\mathrm{a}-\mathrm{d}}$ & $1270.93^{\mathrm{a}}$ & $952.53^{\mathrm{b}-\mathrm{e}}$ & $915.90^{\mathrm{b}-\mathrm{f}}$ \\
\hline Wilis & $842.64^{\mathrm{c}-\mathrm{f}}$ & $680.59^{f}$ & $1006.07^{\mathrm{b}-\mathrm{e}}$ & $1107.51^{\mathrm{ab}}$ \\
\hline Kawi & $827.11^{\mathrm{d}-\mathrm{f}}$ & $1039.88^{b-e}$ & $1124.41^{\mathrm{ab}}$ & $1011.70^{b-e}$ \\
\hline MLG 3209 & $883.47^{\mathrm{b}-\mathrm{f}}$ & $960.99^{\mathrm{b}-\mathrm{e}}$ & $991.98^{\mathrm{b}-\mathrm{e}}$ & $798.94^{\mathrm{ef}}$ \\
\hline MLG 3083 & $821.48^{\mathrm{d}-\mathrm{f}}$ & $1082.15^{a-c}$ & $798.94^{\mathrm{ef}}$ & $884.91^{\mathrm{b}-\mathrm{f}}$ \\
\hline
\end{tabular}

$\mathrm{Ca}$, calcium; $\mathrm{Al}(\mathrm{ec})$, aluminium exchangeable. a,b,c,de,, Values numbers followed by the same letter were not significantly different at Duncan's multiple range test $5 \%$.

Table 6. Effect of liming on potassium and sodium uptake in leaves of soybean genotypes.

\begin{tabular}{lcc} 
Genotypes & K $(\mathrm{ppm})$ & Na $(\mathrm{ppm})$ \\
W 3898-14-3 & $23,040.69^{\mathrm{a}}$ & $256.71^{\mathrm{a}}$ \\
Wilis & $18,966.93^{\mathrm{b}}$ & $222.11^{\mathrm{b}}$ \\
\hline Kawi & $23,604.36^{\mathrm{a}}$ & $256.71^{\mathrm{a}}$ \\
MLG 3209 & $21,862.12^{\mathrm{a}}$ & $235.95^{\mathrm{ab}}$ \\
\hline MLG 3083 & $18,864.45^{\mathrm{b}}$ & $215.19^{\mathrm{b}}$ \\
\hline
\end{tabular}

$\mathrm{K}$, potassium; $\mathrm{Na}$, sodium. ${ }^{\mathrm{a}, \mathrm{b}}$ Values in the same column followed by the same letter were not significantly different at Duncan's multiple range test $5 \%$.

uptake of $\mathrm{Na}$ in the leaves and was significantly different from susceptible genotype MLG 3083. Na influx into plant cells occurred by active transport (Taiz and Zeiger, 1991), which had no impact on the uptake of $\mathrm{Na}$, despite it increased in the soil due to liming. In other words, increasing $\mathrm{Na}$ in the plant did not affect soil $\mathrm{Na}$ availability, but the increase of $\mathrm{Na}$ in the plant was caused by plant active absorption. This indicates that plants need $\mathrm{Na}$ in the physiological process and not as an influxing excessive nutrient due to the high $\mathrm{Na}$ availability. A similar result was reported by Maas et al. (2000) that studied the improvement of soil acidity by using sea water and reported that the application of higher sea water levels led to a higher suppression of Al.

\section{Conclusions}

Different genotypes had different different nutrient uptake. At different level of liming, the contents of $\mathrm{K}$ in the roots and $\mathrm{Ca}$ in the leaves were also different among the genotypes. Acid-tolerant genotypes and acid-susceptible genotypes did not show any difference in terms of uptake of $\mathrm{Ca}, \mathrm{Mg}$, and $\mathrm{Al} /(\mathrm{Ca}+\mathrm{Mg})$ ratio in the roots, and $\mathrm{Mg}$ and $\mathrm{Al} /(\mathrm{Ca}+\mathrm{Mg})$ ratio in the leaves. The differences in the uptake of these nutrients were more influenced by liming levels rather than by the genotypes. $\mathrm{K}$ and Na uptake were not affected by the liming levels, but they were influenced by the genotypes. Acid-tolerant genotypes W 389814-3 and Kawi had a higher $\mathrm{K}$ and $\mathrm{Na}$ uptake than susceptible genotypes.

\section{References}

Andric L, Rastija M, Teklic T, Kovacevic V, 2012. Response of maize and soybeans to liming. Turk J. Agric. For. 36:415-20.

Basri IH, Naim T, Kennedy J, 1991. Residual effect of calcite and K fertilizer application on soil pH, K, Ca, and Mg availability and absorb- tion by soybean. Pemberitaan Penelitian Sukarami 19:39-42.

Bhalerao SA, Prabhu DV, 2013. Aluminium toxicity in plants - a review. J. Appl. Chem. 2:447-74.

Blamey FPC, 2003. A role for pectin in the control of cell expansion. Soil Sci. Plant Nutr. 49:775-83.

Bojarczuk K, Oleksyn J, Karolewski P, Żytkowiak R, 2006. Response of silver birch (Betula pendula Roth.). Seedlings to experimental variation in aluminum concentration. Polish J. Ecol. 54:189-200.

Bose J, Babourina 0, Renge Z, 2011. Role of magnesium in alleviation of aluminium toxicity in plants. J. Exp. Bot. 62:2251-64.

da Silva IR, Corrêa TFC, Novais RF, de Oliveira Gebrim F, Nunes FN, da Silva EF, Smyth TJ, 2008. Protective effect of divalent cations against aluminum toxicity in soybean. R. Bras. Ci. Solo 32:2061-71.

Foy CD, 1984. Physiological effect of hydrogen, aluminum, and manganese toxicities in acid soil. In: F. Adams (Ed.), Soil acidity and liming. American Society of Agronomy, Inc., Madison, WI, USA, pp 57-97.

Ferrufino A, Smyth TJ, Israel DW, Carter TE, 2000. Root elongation of soybean genotypes in response to acidity constraints in a subsurface solution compartment. Crop Sci. 40:413-21.

Keltjens WG, 1990. Effects of aluminum on growth and nutrient status of Douglas-fir seedlings grown in culture solution. Tree Physiol. 6:165-75.

Lee HS, 1989. Effect of soil acidity on growth, yield and it's varietal differences in soybean. pp 1030-1035 in A.J. Pascale (Ed.), ACTAS Proceedings. World Soybean Research Conference IV, Buenos Aires, Argentina.

Liu L, Luan L, 2001. Internal aluminum block of plant inward K channels. Plant Cell 13:1453-65.

Loide V, 2004. About the effect of the contents and ratios of soil's available calcium, potassium, and magnesium in liming of acid soil. Agron. Res. 2:71-82.

Maas A, Sutanto S, Purwadi T, 2000. Effect of sea water on the rate of pyrite oxide and nutrients of acid sulfate soil. J. Ilmu Tanah dan Lingkungan 2:41-5. [in Indonesian].

Meriño-Gergichevich C, Alberdi M, Ivanov AG, Reyes-Díaz M, 2010. $\mathrm{Al} 3+-\mathrm{Ca} 2+$ interaction in plants growing in acidsoils, al-phytotoxicity response to calcareous amendments. J. Soil. Sci. Plant Nutr. 10:217-43.

Nursyamsi D, Osaki M Tadano T, 2000. Effect of aluminum on plant growth, phosphorus and calcium uptake of tropical rice (Oryza sativa), maize (Zea mays), and soybean (Glycine max). Indon. J. Agric. Sci. 1:51-62.

Okada K, Fischer AJ, Salasar FAP, and Romero YC, 2003. Difference in the retention of $\mathrm{Ca}$ and $\mathrm{Al}$ as possible mechanism of $\mathrm{Al}$ resistance in upland rice. Soil Sci. Plant Nutr. 49:889-95.

Pan WL, Hopkins AG, Jackson WA, 1989. Aluminum inhibition of shoot lateral branches of Glycine max and reversal by exogenous cytokinin. Plant Soil 120:1-9. 
Phengshouvana V, Attanandana T, Yost RS, 2009. Lime application to two acidic upland soils for soybean production in Champasak Province, Lao PDR. Kasetsart J. Nat. Sci. 43:19-27.

Poolpipatana S, Hue NV, 1994. Diferential acidity tolerance of tropical legumes for green manure in acid sulfate soils. Plant Soil 163:131-9.

Sopandie D, Jusuf M, Anwar S, Supijatno, 2000. Physiological basis of differential aluminum tolerance in soybean genotypes. In Gunawan LW, Sunarlim N, Handayani T, Soegiarto B, Adil WH, Priyanto B, and Suwarno (Eds.), Proceeding of Research and Development of Soybean Production in Indonesia. Indonesian Agency for Agricultural Research and Development; The Ministry of Science, Research and Technology of German; Jakarta, Indonesia, pp 105-110.

Sunarto, 1985. Study of physiology and genetic of soybean tolerance to aluminum toxicity. Doctorate Disertation. Bogor Agricultural University, Indonesia. [in Indonesian].
Taiz L, Zeiger E, 1991. Plant Physiology. The Benjamin/Cummings Publishing Company Inc., New York, NY, USA.

Vardar F, Unal M, 2007. Aluminum toxicity and resistance in higher plants. Adv. Mol. Biol. 1:1-12.

Wang JW, Kao CH, 2004. Reduction of aluminum-inhibited root growth of rice seedlings with supplemental calcium, magnesium and organic acids. Crop Environ. Bioinf. 1:191-8.

Watanabe T, Okada K, 2005. Interactive effects of al, ca and other cations on root elongation of rice cultivars under low $\mathrm{pH}$. Ann. Bot. 95:379-85.

Watanabe T, Osaki M, 2002. Mechanisms of adaptation to high aluminum condition in native plant species growing in acid soils, a review. Commun. Soil Sci. Plant Anal. 33:1247-60.

Yan J, Chen JB, Zhang TT, Liu JX, Liu HB, 2009. Evaluation of aluminum tolerance and nutrient uptake of 50 centipedegrass accessions and cultivars. Hortsci. 44:857-61. 